Sabira STÅHLBERG (Helsinki) \& Ingvar SVANBERG (Uppsala)

\title{
Sarana in Eurasian folk botany
}

\section{Introduction}

Travelling in Kamchatka in 1740, lieutenant Sven Waxell (1701-1762), the Swedish second-in-command to Vitus Bering, mentions a yellow lily called sarana by the local Itelmen (Kamchadal). The bulbs of sarana were harvested for food:

They also dig up yellow lilies, which grow in abundance and are known as Sarana. They dry the bulb of this plant and then pound it into a kind of flour, which they use to thicken their soups; when they wish to eat something extra delicious, or serve an especially fine dish to a guest, they make pancakes out of this flour mixed with water. These pancakes are then fried in fish fat and I have eaten them frequently with great pleasure. (Waxell 1953: 138-139; translation by the authors.)

More than a century after Waxell, German explorer Friedrich Heinrich von Kittlitz also observed a plant called sarana in Kamchatka. This flower was purpleblack, but it did possess a bulbous root, which was of great importance as a food article for the local people:

Auf der Ebene bemerkten wir viel soeben in die Blüthe getretene Sarannah mit purpurschwarzen Blume (Fritillaria Saranna), deren rundliche Wurzelknolle von so grosser Wichtigkeit als Nahrungsmittel ist und in den meisten Haushaltungen im Innern des Landes noch jetzt, wie vor der Eroberung durch die Russen, die Stelle des Brods und der Mehlspeisen überhaupt einnimmt. (Kittlitz 1858: II: 218.)

Waxell speaks about a yellow lily, von Kittlitz about a purple-black flower. Other travellers to Kamchatka describe the starchy bulbs of sarana as similar to onion or garlic in aspect and somewhat sweet in taste when cooked. They agree on the importance of sarana roots in the diet of the local population, but the scientific identifications of sarana leave much to be desired. A plant called Fritillaria saranna does not exist. A Fritillaria, although this group together with the Allium and Lilium groups belongs to the large family of lilies, Liliaceae, cannot be mistaken for a Lilium. How, then, should sarana be identified? 


\section{I.I. Purpose of the study}

Sarana is a popular plant name in Turkic and Mongolian languages as well as in Russian and in several languages of Siberia. The bulbs of this plant, or plants, according to evidence in literature and travel accounts, have traditionally been used for food in northern Eurasia, from the Volga-Ural region in the west to the coastal areas of the Pacific in the east. The bulbs played an important, sometimes even essential role in the nutrition and economy of several groups. Also on the other side of the Pacific, in Alaska and on the Canadian west coast, sarana roots have been gathered and used as a food article by indigenous peoples. The use of sarana has diminished, if not entirely disappeared, along with traditional ways of life during the past century. Knowledge and techniques connected to sarana have been forgotten, and the plant name has often disappeared from everyday language use. There is, though, some revival in the tradition of gathering sarana at least among the Itelmen in Kamchatka (Koester 2002: 5152). Some of the plants called sarana can nowadays be found on the list of endangered plants in Siberia.

This article tries to identify which species are included under the plant name sarana in northern Eurasia, and to some extent, in northern America. It discusses how the plants have been gathered and used, and the significance of sarana in the nutrition, traditions and economy of peoples in Eurasia and the Pacific area. The article is an ethnobiological contribution to the understanding of the complex activity context between humans and plants. Contemporary ethnobiology aims at studying the biocultural domains that develop in the relations between human beings and other biological organisms. Ethnobiological data have to be culturally and socially contextualised, and they not only answer the question how a plant has been of importance, but also to when, where and by whom (Svanberg 2004b: 10).

The analysis of the plant name and use of the plants called sarana is important not only in the field of ethnobiology, but also sheds some light on linguistic, cultural and economic contacts and development of northern Eurasia. Research on the peoples in northern Eurasia has traditionally concentrated on linguistic and ethnographical data. Nutrition and activities connected to the subsistence of the local people are sometimes described but seldom analysed within their context, although subsistence forms the base for all other human activities. Especially in societies largely dependent on wild plants and animals, the gathering, hunting or fishing, conservation and preparation of food takes up much of the time and attention of the people. This reflects on the society as a whole, its economy and culture, and defines and creates social relationships. These factors in turn influence the environment, through for instance overuse of some resources due to economic interests, or through transition to some degree of agriculture in order to have controlled access to certain plants.

The analysis of sarana is only one example of this complex relationship be- 
tween humans and their environment. Today when most kinds of food articles are available all year round we tend to forget how directly dependent humans were on locally available biological resources only a few generations ago (in certain areas people are still dependent) and how much effort was put into collecting sufficient nutrition. Tracking sarana in northern Eurasia and America not only documents the traditions and life of the peoples and broadens the perspective of traditional ethnology into other fields, but also opens up questions about changes in social, cultural and economic patterns.

\section{I.2. Sources and methods}

This study is based mainly on travel accounts from the 18th and 19th centuries, botanical analyses and linguistic data. The available information on sarana is scarce, scattered and contradictory, although explorers and travellers in the Russian empire frequently mention plants with this name. It seems that sarana was widely used for food among various ethnic groups, including Russians, in the European part of Russia, Siberia and the Far East. There is almost no modern research available on sarana (an exception is Fremstad \& Paal 1993), and as far as we know there have been no previous attempts to analyse the plants or their use from a wider geographical perspective or over a longer time span.

One of the reasons for the lack of coherence is that few of the travellers who mention sarana were botanists (an exception is, for instance, Johan Peter Falck) or even primarily interested in botany. Their main aim was to explore, map and describe formerly unknown regions and peoples. They were often influenced by contemporary ideas of civilisation and prejudices toward foreign habits, as well as by gender and the social group they came from - most were upper-class European males. All this narrowed the scope and contributed to inaccurate identifications and superficial information on the gathering and use of plants, which were indigenous, often female occupations. Further, botanical classification at the time of most of the journeys was only developing. The pioneering work of Swedish botanist Carl von Linné dates to around the middle of the 18th century. During the 19th century botany developed immensely and later travellers could draw upon earlier travel accounts and also on extensive botanical literature and knowledge.

We have chosen a regional approach to the analysis of sarana, based roughly on the identifications and ways of using sarana bulbs. In modern ethnobotany the focus is on the relationship between humans and plant, and this relationship is analysed within the context of the social and natural environments. A purely linguistic or ethnological approach would not be sufficient, because the ethnobotanical analysis requires a much wider span in time and space and takes into consideration many aspects that do not fit into these more traditional research models.

Our dividing lines for the identification and use of sarana run along the 
Ural and around the Pacific Rim. West of the Ural line sarana signifies mostly lilies (Lilium species). In this mainly agricultural area sarana roots have been used during the 18th and 19th centuries as an addition to the diet. There is least information on the use of sarana from this area, which could be explained by a gradual discontinuation of gathering practices due to changing economic conditions, which in turn can have changed the natural environment and the availability of wild-growing roots like sarana.

In Central and North Asia, including Siberia, sarana mostly signifies lilies, but the name also includes some fritillaries in the eastern parts. In this area there is some agriculture but most of the peoples lived until fairly recently on gathering, hunting, fishing and animal husbandry. From this area there is comparatively more information on sarana, especially from northeastern Siberia and the Baikal region.

Most recently sarana has been used on both sides of the Pacific. Here sarana means mostly fritillaries but also some lilies. This region is characterised by a very complex use of sarana. At the beginning of the 20th century traditional gathering activities were practiced in the area and even now fritillaries are used as additional food in some regions at the Pacific Rim, notably Kamchatka and northern America.

Finally, Kamchatka will serve as example for an analysis on the gathering practices, conservation, the culinary use and economic, cultural and social significance of sarana. The example of Kamchatka cannot be directly used as a historical development model for other regions due to, among others, climatic and natural conditions. There is some reason, though, to believe that the social and economic changes triggered by the arrival of the Russians bear similarities to those that have taken place in the Volga-Ural region and Central and North Asia.

\section{Botanical excursion: lilies and fritillaries as food}

Sarana is often identified as a lily. In history lilies have been widely used as food articles in Europe and Asia. Different species of Lilium as food and medicine are known from middle and southern Europe and from most of northern and eastern Asia, as well as among North American native peoples. Most widespread is the turkscap or martagon lily (Lilium martagon), Lilium dauricum (also called pensylvanicum), Lilium spectabile and the coral lily, Lilium tenuifolium (now pumilum), which are all well known as food ingredients in northern Eurasia. In Europe madonna lily (Lilium candidum) has been used in medicine and sometimes as food at least since Roman times, whereas other lilies, such as the martagon lily, pyrenean lily (Lilium pyrenaicum), red lily (Lilium pomponium), orange lily (Lilium bulbiferum), scarlet turkscap (Lilium chalcedonicum) and Caucasian lily (Lilium monadelphum) are known from medicinal use 
in the 16th and 17th centuries. In China and Japan the orange tiger lily (previously Lilium tigrinum, now Lilium lancifolium) has been grown for food and used in medicine for at least a millennium. The martagon lily, golden rayed lily (Lilium auratum), Brown's lily (Lilium brownii), David's lily (Lilium davidii), Leichtlins' lily (Lilium leichtlinii) and Miyamasukashi lily (Lilium maculatum) have been used or are still in use. Ainu on the Kurilian Islands gathered and consumed among others Lilium pensylvanicum. In eastern Asia many of the lilies give not only their roots but also their flower buds for food (Tanaka 1976: 430; Le Strange 1977: 162-165; Svanberg 2004a: 20; Lundquist 2005: 66-77).

North American native peoples have used the bulbs of the Canadian lily (Lilium canadense), Columbian lily (Lilium columbianum), eureka lily (Lilium occidentale), leopard lily (Lilium pardalinum), Sierran tiger lily (Lilium parvum), wood lily (Lilium philadelphicum) and swamp lily (Lilium superbum) for soups and gruels as well as for medicine. Apart from lilies, but used in a similar way and often confused with lilies, in North America and eastern Siberia the bulbous fritillaries, Fritillaria, were prepared for food. A plant called black sarana (or Kamchatka lily, Kamchatka fritillary, black lily, chocolate lily, northern rice root; all commercial names for Fritillaria camschatcensis) still exists on the international market and is used as a food article (Le Strange 1977: 162-165; Turner et al. 1990: 126; Moerman 1998: 306-307). Also in Japan the bulbs of Fritillaria camschatcensis have been dried for the winter (Tanaka 1976: 319).

\section{Sarana in the Volga-Ural region}

The plant name sarana has been recorded among Turkic peoples and Russians as well as among some of their Finno-Ugric neighbours in the Volga-Ural area. In the Sverdlovsk region in the Russian federation there is even a village called Sarana. Usually in the Volga-Ural area sarana signifies a lily. In Volga Tatar, sarana or sar'na means 'an onion-like, bulbous plant', 'a lily' (Radloff 1911: IV: 317; Räsänen 1969: 403).

Travelling in Russia in the 1770s, Peter Simon Pallas mentions that Cossacks at the Volga utilised sarana bulbs for food. In this case sarana has been identified as martagon lily (Lilium martagon) (Hedrik 1919: 336). In other cases the scientific identification of sarana is not very clear. Johan Peter Falck listed in 1785-1786 several plants of southeastern Russia and Siberia, among them a red lily, Lilium pomponium, which according to him was known as saranna among the Tatars. The identification cannot be correct, because Lilium pomponium grows only in the southern parts of the Mediterranean area and is unknown elsewhere. He possibly meant coral lily, Lilium pumilum, which is red in colour as well. Johan Peter Falck also tells that the Tatars called the violet or 
purple martagon lily tschep saranna, so that it would not be confused with the already mentioned red saranna lily (Svanberg 1987: 79; 1998: 108).

The roots Bashkir historian and political activist Zeki Velidî Togan describes in his memoirs are even more difficult to identify than the sarana of Falck. The memoir of Togan shows indirectly that the main focus of the people in his home village was on cultivated food articles. Not only potatoes function as criteria for sarana, but also gathering sarana seems to have been a marginal activity. As a boy Togan (born in 1890) used to gather "wild potatoes called sarana" and other roots in the spring, "found where the snows had cleared, cooking and eating them" (Togan 1969: II). In Bashkir, variations of sarana, harana, har'na or harïna, usually signify 'a lily' or 'a multi-coloured lily'. We can therefore guess that Togan gathered lily bulbs. In Chuvash, sarana means 'a lily, an onion-like [bulbous] plant, a plant with red flowers, a plant with yellow roots, a grass-like plant with edible roots, which are used against jaundice'. Sarana in Chuvash seems, though, to be a loan from Russian or Tatar (Fedotov 1996: II: 17). This is certainly the case in neighbouring Finno-Ugric Mari, where sarana carries the meaning of bishop's goutweed (Aegopodium podagraria) (Räsänen 1923: 59; 1969: 403).

Ingeborg Hauenschield, in her compilation of Turkic popular plant names, lists sarana as a Russian word for Lilium martagon in Chuvash and in Xinjiang Kazakh. From Hauenschield's study it becomes evident that the popular names for martagon lily differ widely from each other in Turkic languages, for instance Altai sargaj, Bashkir sïbir lele, Khakass sip, Yakut (Sakha) mono, khorun, ïmijach, Kazakh bujra lalagül and Tuva aj (Hauenschield 1989: 198). On the other hand, her study shows that sarana signifies some non-Lilium species among the Turkic peoples in Russia and Xinjiang. In Tatar and Chuvash species of Corydalis are called säränä or sarana (Hauenschield 1989: 58). The Chuvash call the white water-lily (Nymphaea alba) and the cowslip (Primula veris) sarana (Hauenschield 1989: 116, 134).

In Russian sarana or saranka (саранá, сара́нка) is considered a Tatar loanword with intact Turkic pronunciation. As in Volga Tatar, it mostly implies a lily or an onion-like or bulbous plant, but it also signifies some other species. Often sarana is identified as coral lily, Lilium tenuifolium (pumilum), or martagon lily, Lilium martagon. Variations of sarana are popularly distinguished through colour or place of growth. Yellow sarana, saraanka (желтал сарана, сараанка) is interestingly enough identified as Lilium martagon, even though the martagon lily rarely carries yellow flowers. Mostly this lily is purple, violet or white with yellow seedpods. Field sarana (сарана полевая) is identified as 'the Siberian red lily, Lilium tenuifolium'. Both the yellow and the field sarana have edible roots. Forest and large sarana (лесная и большая сарана) are identified as Lilium spectabile. Wolf (волчья) sarana, "the Siberian yellow sarana", is identified as the East Siberian day lily, Hemerocallis flava (compare 
chapter 4: H. fulva in Kazakh. H. flava is an older, more general definition for variations of Hemerocallis, including $H$. fulva). The literary name for sarana is tsar's curls (иарские кудри) (Radloff 1911: IV: 137; Dal' 1955: IV: 138; Dimitriev 1958: 46; Shipova 1976: 279; Fedotov 1996: II: 17).

Dal' (op. cit.) mentions further that baduj or badun (бадуй, бадун) is another name for Lilium martagon or Siberian Hedysarum, in Russian popularly called kореес́nik (копеечник). According to Dal', baduj means 'a yellow lily, sarana, an oil-giving plant [three names], rock-biter, tsar's sceptre, tsar's curls, ovsjanka' (желтая лилия, сарана, масло, масленок, масленка, скалозубеи, иарский скипетр, иарские кудри, овсянка).

'Rock-biter' could signify a plant that grows on rocks. 'Tsar's curls' probably describes the aspect of some of the Lilium species, among them martagon lily, which have bright-coloured flowers and petals that curl. 'Tsar's sceptre' maybe refers to the straight, strong stem of the Lilium species that makes the flowers look as sceptres, and it can also be a reference to the tsar's curls. The last name, ovsjanka (овсянка), is used for grasses that resemble oat, which takes it very far from any similarity to Lilium or Hedysarum species. We will discuss the identification of ovsjanka in greater detail below within the context of the Pacific Rim.

As an interesting addition to the Russian use of the plant name sarana, the word for locust (Gryllus migratorius) in Russian is saranča (саранчa), and the rose-coloured starling (Sturnus roseus) mainly eating crickets is called sarančejadec (саранчеядеи), 'locust eater' (Dal' 1955: IV: 138).

Gathering sarana seems to have been more common in the region of northern Eurasia, where cultivation of crops was difficult due to soil or weather conditions, rather than in the Volga-Ural region, where agricultural practices were widespread among the population in the 18th and 19th centuries. It seems that by this time gathering sarana had become (or maybe always was) a marginal activity, a supplement to the main diet consisting of animal and agricultural products. In short, sarana gathering was an activity comparable to the gathering of mushrooms in, for instance, Russia or Finland.

\section{Sarana in Central and North Asia}

In Central and North Asia, including Siberia and the steppe area, the name sarana is used in Turkic, Mongolian and Tungus languages for a range of plants, but mostly for species of Lilium. In Kazakh, sarana signifies except for martagon lily also the orange day lily (Hemerocallis fulva), and among Kazakhs in Xinjiang it means sun hemp (Crotolaria juncea) (Hauenschield 1989: 59, 86).

In Mongolian there are two saraana (сараана, Buryat variation haraana): buržgar saraana (буржгар сараана) and namhan saraапа (намхан сараана). 
They are identified as 'Lilium martagon and Lilium tenuifolium', 'Lilium pumilum or Lilium concolor' respectively (Suzue 1933: II: 958; Cheremisov \& Rumyantsev 1937: 293; Bawden 1997: 296; Anikin 2000: 484). These definitions require a correction. Lilium tenuifolium and Lilium pumilum are synonymous for coral lily and the correct name today is Lilium pumilum. Another meaning of saraana is wild garlic or rocambole (Allium nipponicum). Džolu saraana means 'a kind of plant with an edible root, Colocasia antiquorum', which is synonymous with Colocasia esculenta or imperial taro (Suzue 1933: II: 958; Lessing 1960: 675; Räsänen 1969: 403; Fedotov 1996: II: 17).

In one of the oldest botanical surveys of Siberia, Flora Sibirica from 1747, Johann Georg Gmelin identifies quite a few lilies as sarana. Among them there is a red lily the Russians call field sarana. A modern identification of this plant is difficult to reconstruct on the basis of the given description, but most likely field sarana signifies the coral lily (Lilium pumilum; compare chapter 3). Gmelin also identifies Lilium reflexum as the plant Mongolian Dagurs call sarana. He adds that bulbs of Lilium species are used by Tungus (Evenki), Buryat and Yakut (Sakha) for food, "and all are called sarana". In the opinion of Gmelin, the Tungus name sarana is a Russian loanword. Russians in Siberia differ between white, that is sarana with white roots, tooth-possessing, that is sarana with cloves that look like teeth in the root, and field sarana, growing in the fields. Another species of a mountain lily with red flowers, which grows throughout Siberia, is called sarana as well, according to Gmelin; in Kamchatka its name is sarana ovsjanka, and its roots are eaten (Gmelin 1747: I: 41-43). Probably the white sarana of Gmelin is a fritillary; the others will be discussed in the context of the Pacific Rim (chapter 5).

Also Kerstin Eidlitz (1969: 48) mentions that sarana was utilised by many peoples in Siberia. It seems to have been particularly important for the Turkicspeaking peoples in southern Siberia, such as the Shor, Tofalar, Tuva and Altai, but also for the Buryat, Selkup and Itelmen. Evenki and Khanti from the Turukhan area gathered, dried and made flour from starchy sarana bulbs, as did Buryat groups at the Baikal (Tret'yakov" 1871: 442; Tugutov 1958: 157). In southern Buryatia milk products were spiced with sarana bulbs, called häbläg or tymähän. Airuul, made of milk, was spiced with autumn sarana bulbs and sugar, and it was a dish highly appreciated by the local people. Sometimes intestines of sheep or cow were filled with the thick airuul mass and additional sarana bulbs and sugar. This "sausage" was considered to be proper food for journeys. Even during the first years of collectivisation in the 1930s, students from the southern districts often came to Ulan-Ude, Kyakhta, Irkutsk and other cities carrying with them these homemade sausages and sarana bulbs (Tugutov 1958: 157; see also Gmelin 1747: I: 42 and Hudgins 2003: 131-152).

The Shor in the basins of the Mrassa and Abakan ground sarana bulbs into flour. They removed the soil from the root, boiled the bulb and dried it in the 
sun. Then they ground it into flour, which they could use for baking bread. L. P. Potapov (1953: 62) mentions that the now extinct peoples of the Altai-Sayan uplands employed the same method. According to Wilhelm Radloff (1884: I: $355)$ the Shor gathered martagon lily (Lilium martagon) and other edible roots, such as dogtooth violet (Erythronium dens-canis), anomalous peony (Paeonia anomala) and ramson (Allium ursinum). These were often dried in the sun and then used immediately or stored for the winter.

The Yukaghir cooked porridge out of the roots of Lilium martagon. Kai Donner notes, "The only vegetable food article they know how to use, except for berries, is the root of a plant, the martagon lily, which grows at one of the rivers and has thick, white roots". These roots were cooked into a thick porridge. Also the Selkup cooked sarana bulbs into porridge (Donner 1915: 173).

Travellers and explorers to eastern Siberia tell that the Negidal women gathered wild onions, sarana, stub-wort, coltsfoot and other roots. Ket at the Yenisey, Orochi near Khabarovsk and Nivkhi (Gilyak) on Sakhalin and the lower Amur gathered sarana bulbs as well. Among the Nivkhi gathering was the occupation of women and children as well as young adults. They collected except for sarana roots also acorns, nuts and berries. In family plots they cultivated sarana and other valuable plants (Katanov 1891: 152; Jochelson 1910: 418). Unfortunately there is no information on what kind of sarana was collected, so a scientific identification is impossible.

Kerstin Eidlitz (1969: 48) shows in her collection of information on the use of sarana among the northern peoples of Russia that the identification can be very confusing. Sometimes sarana is identified as Lilium martagon or other lilies, sometimes as Fritillaria kamtjatka [sic] and even as Fritillaria saran(n)a. The last two are with great probability synonymous with the Kamchatka fritillary, Fritillaria camschatcensis, which is still in use as food on the Pacific Rim.

A review of Central and North Asia shows that for many of the peoples sarana was an important part of the diet, and there is also concrete information on using sarana bulbs. The presence of animal husbandry is reflected on the diet, supplying for instance milk, which is used together with wild plants. A social aspect is also mentioned: Gathering was an occupation for women and the young. There is only one case where sarana is mentioned to be cultivated, but it shows that sarana was considered locally very valuable and its cultivation was worth the effort and time.

\section{Sarana at the Pacific Rim}

On Kamchatka gathering sarana was very common among Itelmen, Koryak and Russians. There is some information that the Chugach Inuit and Aleut collected sarana as well (Margaritov 1899: 80; Birket-Smith 1953: 42; Eidlitz 1969: 48). According to captain James Cook during his journey 1784, the principal vege- 
table of the Aleut was saranna or lily root, which is described to be the size of a garlic root, round, and composed of a number of small cloves and grains. Cook states that when boiled it somewhat resembles saloop. He found the taste not unpleasant, but it did not appear to exist in any great abundance (Hrlicka 1945: 92). Also Grigori Schelechof, travelling from Okhotsk to America, mentions the use of sarana and lily bulbs around the Bering Strait and on the North American islands. Sarana bulbs were used side by side with roots of alpine bistort (Persicaria vivipara) and other roots, which according to Schelechof must be counted among the most important local food articles in the region (Schelechof 1793: 4, 33). Interestingly enough, there is a place called Sarana Bay on the Akutan Island near Alaska.

Russian explorer Stepan Krasheninnikov, who travelled in Kamchatka in the early 19th century, tells about a sarana he had not observed anywhere else. "Important nutrition for the local population", he writes, "provide grasses and roots that compensate for the lack of bread and fish. The most significant is sarana, which is used instead of grain." Krasheninnikov then gives a description of the plant. He identifies sarana as a lily, Lilium kamtschatense in his opinion, and adds, quoting Gmelin's Flora Sibirica from 1747, that it is also called white sarana because of the colour of its root, tooth-possessing or field sarana. "The stem is thick as a swan feather or thinner; lower down it is reddish, and along the stem green leaves grow in two rows. The lower consists of three and the upper of four leaves that form a cross. At the top there is a dark purple ("sourcherry") coloured flower, more seldom two bright flowers that resemble lilies and are somewhat smaller. The root is called sarana and is as big as an onion, and consists of many small, round cloves. Therefore it is also called round sarana" (Krasheninnikov 1819: II: 312-313).

Krasheninnikov's and Gmelin's identifications are quite inaccurate. Sarana in Kamchatka and eastern Siberia cannot be identified solely as species of Lilium. According to the description, the white or round sarana is not a Lilium but fritillary, Fritillaria camschatcensis, which carries purple-black flowers and possesses a white root that looks like cooked rice. The tooth-possessing sarana is on the other hand likely to be a different plant, a Lilium, which has a root formed by cloves. Also the field sarana is probably a Lilium (compare chapter 3).

F. H. von Kittlitz lists quite a few sarana from his journey to Kamchatka. One of them is a fritillary, another a yellow or yellow-red lily called ovsjanka (compare above with Gmelin, who indicates ovsjanka as a red flower). "The edible bulbs or roots in the region," says von Kittlitz, "were numbered to me as follows: sarannah with a purple-black flower (Fritillaria Saranna, kamchadal Augtsch), Ofsjanka (Lilium debile, yellow sarana) and Awunik which bulb is similar to the previous". The last one is identified by von Kittlitz as "a yellowred lily, Lilium japonicum" with a question-marked reference to Thunberg (Kit- 
tlitz 1858: II: 321-322). Lilium japonicum is, though, usually white or pinkish white and there is no record of it in Kamchatka. Lilium debile is mostly bright orange in colour. Fritillaria sarana, which does not exist as a plant name, is identifiable as Fritillaria camschatcensis. Von Kittlitz observed these "black Sarannah lilies" grow in great numbers on a high plateau in fields with low grass (Kittlitz 1858: II: 256). David Nelson, botanist on captain James Cook's ship Resolution, visited Kamchatka in 1778 and mentions that the natives ate bulbs of a plant with flowers of "an exceeding dark red colour", which also points to Fritillaria camschatcensis (Clark 1976; Coffey 1993: 305).

Von Kittlitz adds in a footnote three more sarana growing in Kamchatka:

Wostronofscha, Knolle ebenfalls der Ofsjanka ähnlich, ist kleiner, die Blume soll grün sein, wächst im Walde. Gussinaja sarannah (Gänse-sarannah, kamtsch. kofatatsch) $=$ Sumpfpflanze, von der die Wurzel als Nahrung benutzt wird; Mochnaschta - weiss, auch Sarannah genannt. (Kittlitz 1858: II: 321-322.)

About the identity of these sarana we can only speculate. Most probably they are neither Lilium nor Fritillaria, but are called sarana because of the similar form of their roots, or the use of their bulbs as food.

An earlier traveller to eastern Siberia, Adolph Erman (1828-1830), identifies "the delicious lily bulbs" of round sarana as Fritillaria, also calling it Fritillaria sarana, and ovsjanka as a yellow Lilium, a close relative to Lilium martagon. Erman has, though, more to tell about the goose sarana:

Man erzählte mir dass ausser dieser [runde Sarana] und der Owsjanka, das sind die Knollen einer gelbblühenden dem Lilium martagon zunächst stehenden Art, bei Uschkina noch eine dritte geärntet werde, die man Gusina$j a$ d. i. die Gänse Sarana nenne, weil in der That die Gänse sie eben so begierig wie die Menschen suchen und ausgraben. Ihre Blätter schwimmen auf der Oberfläche stehender Wasser (na oserach, d. h. auf den Seen). Man könne die Wurzeln dieses Gewächses nur in gewissen Jahren, wenn die gleichen Seen austrocknen, auf deren Boden sammeln. (Erman 1848: III: 398.)

Erman also tries to identify the goose sarana:

Es dürfte wohl diese keine Lilienart sondern weit eher eine Aroidee sein, deren fleischige Wurzeln, wie die von Calla palustris in Schweden und von den angebauten Arum-Arten (dem Taro und Kalo) auf den Südseeinseln, trotz des scharfen Stoffes den sie alle enthalten, gegessen werden. Wie die Kemtschiga so scheine aber bis jetzt leider auch die Gusinaja Sarana den Europäischen Reisenden auf Kamtschatka ganz besonders unzugänglich. (Erman 1848: III: 398.) 
Kemčiga or kmtschg was described a few decades earlier than Erman by another traveller, Georg Wilhelm Steller. He counted it among the five different plants called sarana in Kamchatka. Most of Steller's descriptions of sarana are largely insufficient for identification, and he did not see more than a few of them in reality:

Sarana auf Tatarisch, Augtsch auf Itälmenisch, sind teils Zwiebeln von tückishen Bund Lilien, Lilium reflexum genannt, teils die Knollen von andern Zwiebel-Gewächsen. Es sind eigentlich auf Kamtschatka fünf Sorten davon bekannt.

1. Kmtschg wächset am Tigil und Chariasowka, sehen wie grosse Zuckererbsen aus, und kommen ihnen beinahe am Geschmack bei, wenn sie gekocht werden.

2. Augtsch oder runde Sarana sind die Zwiebeln vom Lilio reflexo flore atro purpureo in meinen Observationen.

3. Ovsanka sarana, auf Itälmenisch Tmük, sind noch nicht von mir beschrieben.

4. Titchpu wächset an Püstra, dieses Zwiebelgewächst habe ich gleichfalls noch nicht in der Blüthe gesehen.

5. Mattaeit sind die Bulbi satyrii sowohl rubri als albi. (Steller 1774: 90-91.)

Interestingly Steller identified augtsch or round sarana not as a fritillary, but as a purple Lilium reflexum, following Gmelin. At the beginning of the 20th century botanist Eric Hultén (1927: 245) identified augtsch as Fritillaria camschatcensis, and Russian ethnographer Jochelson wrote that the Koryaks gathered the roots of a Fritillaria, which he calls Sarana (Jochelson 1908: 578).

Krasheninnikov points out that neither he nor Steller has seen number 1 or number 4 (kemčiga and titihpu in Krasheninnikov's version) in flower. Titchpu grows according to him around fast rivers. Number 5, Steller's mattaeit, Krasheninnikov identifies as hogweed, also called cow parsnip ("Sphondilium folialis, pinnatifidis or Heracleum sphondylium"), and adds that it was called sweet grass. In the local economy it was as important as sarana, because the local people used it not only in sweetmeats, but also in other kinds of food as well as wine (Krasheninnikov 1819: II: 314-315). This is an interesting observation, because hogweed is usually considered toxic and can provoke allergic reactions.

Ovsjanka, number 3 in Steller's list, grows according to Krasheninnikov, who here quotes Gmelin, in all Siberia and it is a bright red lily with bulbs. Its petals curl and the bulbs consist of innumerable small teeth or cloves. Krasheninnikov identifies ovsjanka as Lilium pomponium and adds that it is also called 
tsar's curls. As we noted above in the case of Johan Peter Falck (chapter 3), Lilium pomponium is out of question, as it does not grow outside the Mediterranean area. Krasheninnikov arguments also that the lily called tsar's curls is different from the Kamchatkan oat-sarana, that is sarana ovsjanka in Gmelin's Siberian flora, which, in the words of Krasheninnikov, signifies Carl von Linné's Lilium martagon. Gmelin's sarana ovsjanka would thus be equal to the martagon lily, whereas ovsjanka in Kamchatka should be, according to Krasheninnikov, identified as another species of Lilium, preferably red in colour (Krasheninnikov 1819: II: 314-315; compare Gmelin 1747: I: 45).

This contradicts the description of Erman (1848: III: 398) and von Kittlitz. Both identify ovsjanka as a yellow flower.

Unter den mancherlei Blumen, welche sie zierten, zeichnete sich die gelbe Sarannah-Lilie (= Lilium debile?) besonders aus; wir sahen diese Prachtblume heut' zum erstenmal im Freien zahlreich. Die Blumenkrone hat bei schön orangegelber Färbung die bekannte zierliche Form von Lilium martagon, aber der Stengel ist viel Schlanker und biegsamer als bei diesen. Die Wurzelknolle besteht aus einer Menge zugespisster fleischiger Blätter, die ein wohlschmeckendes und dem Anschein nach sehr nahrhaftes Gemüse geben, aber lange nicht so fest und nahrungsreich sind, als die rundlichen der sogenannten schwarzen Sarannah; man kennt die Pflanze hier unter dem Namen Ofsjanka. (Kittlitz 1858: II: 261-262.)

This description would point not to the orange Lilium debile, but to another, yellow Lilium. Hultén mentions that the bulbs of sarraná or sarraná-ofsjanka are used by the inhabitants of Kamchatka in soups or as porridge, and he identifies this plant, also called avunik, as the yellow-orange wheel lily, Lilium medeoloides. He mentions that an old name for the plant was, according to Steller, tamyk (Hultén 1927: 242).

Generally in the case of eastern Siberia we can identify two different species under the name of sarana: Lilium and Fritillaria. In an earlier study by Svanberg, the lily bulbs collected by Evens on Kamchatka were identified as Lilium martagon (Svanberg \& Lindin 1986: 166), but more likely the bulbs originated from the fritillary, Fritillaria camschatcensis. Modern research done by Eli Fremstad and Jaanus Paal identifies six different plants as sarana in Kamchatka: The already mentioned Kamchatka fritillary (Fritillaria camschatcensis), three lilies (Lilium martagon, Lilium debile and Lilium pensylvanicum), an orchid (Dactylorhiza aristata), and the tuberous spring beauty with whitepink flowers (Claytonia tuberosa). The plant name sarana is, according to Fremstad and Paal, a Russian word for onion or bulb (Fremstad \& Paal 1993: 32).

In Alaska and North America sarana, locally called wild lily, was cooked and eaten like rice. This sarana is identified as Fritillaria camschatcensis (L.), 
and is today called black sarana in commercial plant lists (Moerman 1998: 240). Its bulbs have been gathered by most of the tribes along the Pacific coast in Canada, for instance by Nitinaht and Hesquit on Vancouver Island (Turner \& Efrat 1982: 55; Turner et al. 1983: 85). The Bella Coola in British Columbia have boiled and eaten the bulbs together with sugar and fat (Turner 1973: 199). Kwakiutl in the same province dried the bulbs in the sun and cooked them with oil (Turner \& Bell 1973: 273). Furthermore the bulbs were dried and eaten in fish and meat stews in Alaska, or made into puddings. The bulbs have also been ground to flour in North America (Heller 1953: 119).

\section{Case study: Kamchatka}

Before and for a long time after the arrival of Russians in Kamchatka, sarana bulbs were an essential part of the local diet. The diet depended on roots, plants and berries as well as on hunting and fishing. The local people were capable of feeding themselves completely by gathering plants, among which the bulbs of sarana were central (Fremstad \& Paal 1993: 32). The importance of sarana in the local diet has unfortunately been underestimated. Especially bulbs of the fritillary, Fritillaria camschatcensis, formed a most important food article for the Itelmen household in former times (Hultén 1927: 245).

The capability of the local people to sustain themselves on what they found in the environment, that is bulbs, berries, tubers and plants, as well as hunting and fishing, shows a high degree of specialisation and a wide and detailed knowledge of plants and animals. With the arrival of the Russians, the economy and also the diet gradually changed and today only small pieces of the traditional knowledge remain. We therefore do not know exactly how sarana was prepared, or the amounts collected or needed. We know however that sarana was a common and multi-functional ingredient in the Kamchatkan kitchen: Cooked, fried, boiled into porridge or pudding, raw, dried for flour, packed into fish flour dough and fried or made into pancakes, as well as prepared for guests and celebrations.

\section{I. Gathering sarana}

Sarana bulbs are very economical in comparison to many other roots in terms of size, way of gathering and the extractable nutrition. They can be easily stored and keep fresh for a long time. The sweet taste of sarana certainly added to its popularity. These are probably some of the reasons why sarana was so popular and why people in Siberia even made special tools for gathering the bulbs. According to Matthias Alexander Castrén $(1855: 188,248)$, the Ket had a special word, thilzen, for the tool they used when they dug for bulbs of dugul (t'ukul in Donner's Kamassian dictionary, see Joki 1944: 74a, 85-86), identified by Castrén and Donner as Lilium martagon. 
Not only sarana, but also berries and many roots and plants such as fireweed, Epilobium angustifolium, were collected in Kamchatka. Karl von Ditmar informs that the local people on Kamchatka took good care of the vegetable supplies, gathering all kinds of roots, stems and berries and drying the sarana bulbs and other plants or parts of plants outside their houses (Ditmar 1890: I: 396).

The sarana bulbs were not only gathered from flowers in bloom but also from mice. Adolph Erman mentions that all over Kamchatka sharp hooks, which were used for digging out the "excellent flour fruits, different sorts of sarana, that is lily roots" from mouse holes, were hanging at the houses (Erman 1848: III: 326). Hultén informs that round sarana or Fritillaria camschatcensis, Steller's augtsch, was gathered by means of especially shaped hoes, but also taken from the supply stores of voles (Hultén 1927: 245).

The habit to dig out vole nests for lily bulbs is known from many peoples in Siberia, for instance Sagai, Altai Tatars, Evenki and Itelmen (Pallas 1776: III: 195-196, 350; Manninen 1931: 30; Gunda 1949: 371; 1981: 82). Erman (1848: III: 198) tells that the Koryak collected sarana bulbs from mice. It is in fact a very comfortable way of gathering the bulbs. Arthur Byhan (1909: 9) mentions that on Kamchatka the local people sometimes dug out vole nests in order to find lily bulbs, but Karl von Ditmar informs that the voles' supplies were plundered even daily. He asserts that the bulbs in the vole nests were of excellent quality (Ditmar 1890: I: 767).

Johan Peter Falck, who was well acquainted with the gathering of lily bulbs in the steppe, tells that on the Barabin steppe humans as well as root voles $(\mathrm{Mi}$ crotus oeconomicus) collected bulbs for the winter. The voles could gather up to 10-15 pounds of bulbs in a nest. Therefore the Barabins used to plunder the nests, partly because there was abundance in the stores, and partly because the bulbs were of high quality (Svanberg 1987: 79; 1998: 108). The high quality is a life necessity for the voles, as they depend completely on the collected roots and bulbs, especially in spring when food is scarce. Failing supplies is fatal for the voles. Erman (1848: III: 246) tells that the blackish sarana [fritillary] bulbs must be gathered when the flowers still are in bloom, that is in July-August. The roots would after this rot and become inedible. The bulbs were partly taken from mice, partly through digging up the living plant, says Erman (op. cit.).

The most detailed description on how sarana bulbs were collected from mice or voles on Kamchatka comes from Steller. Every year the local people took supplies from the mice with many ceremonies and using a special instrument. They never killed the mice, informs Steller, but gave something back so that the whole procedure resembled trade:

Alle diese Bulbi sind bei den der kamtschakischen Nation in sehr grossen Werth, werden sowohl rohe als mit Fischen gekocht gegessen; sie machen daraus Piroggen oder Pasteten, Muse, Salamat auf Russisch, da sie in 
Fischfett geröstet werden, und sammlen sie davon alle Jahre einen grossen Vorrat, welchen sie an der Sonne trocknen, teils nehmen sie diesen Vorrat bei den Mäusen mit vielen wunderlichen Zeremonien und Aberglauben ab, und verhält sich die Sache also, dass in welche Jahre viele Mäuse, in demselber bekamen sie auch viele Sarana, welches sie überhaupt mit der Russen Brod vergleiche, wenn sie die Mäuselöcher ausgraben muss solches mit einer instrument von Renntier-hörnern gemacht geschehen, welches sie kosciokas nennen, dabei nennen sie alle Dinge mit anderen und fremden Namen, dass eine ganz andere Sprache herauskommt, Ursache, dass die Mäuse, welche die Landes-Sprache verstehen, diese nicht verstehen wollen.

Wenn sie allen Vorrat herausgenommen, dabei sie niemals eine Maus tot schlagen, legen sie alte Lappen, zerbrochene Nadeln, Kupra, Slatka trawa, Sedernüsse und etwas Sarana hinein, dass es das Ansehen eines Handels haben solle, weil sie ihnen Kleider, Betten, Instrumenten und andere Dinge geben, wenn sie dieses nicht tun, so halten sie davor, werden sich die Mäuse ersausen oder aufhängen und büssen sie folglich ihre Arbeiter dabei ein; sie sprechen auch zu den Mäusen, sie möchte es ja nicht übel aufnehmen, sie hätten solches nicht aus böser Absicht, sondern aus Freundschaft gethan. Da sie nun unter der Sarana andere Wurzeln auftreffen, so speculieren sie sehr philosophisch darüber. (Steller 1774: 91.)

\subsection{Cooking sarana}

The sarana bulbs were seldom used fresh. A few travellers tell that they were eaten raw, but more often the travellers inform that the bulbs were dried, ground into flour, cooked or fried. Erman mentions that when the sarana bulbs [fritillaries] are raw they contain something that tastes bitter, which disappears when they are cooked. During a subsequent journey Erman observed how his fellow travellers cautiously cooked the dried sarana bulbs they carried:

Die hier gesehene Art dieser Knollen, welche kruglaja oder auch bjelaja Sarana, d. h. runde oder weisse Sarana genannt wird, ist von der Grösse einer starken Kirsche, und besteht aus einem sphäroidischen Hauptstock, von welchem weit kleinere eiförmige Nebenknollen mit abwärts gerichteten Spitzen, ausgehen. Sie sind in Ringen um den Hauptstock gestellt, so dass die ganzen Knollen den Erdbeeren ziemlich ähnlich sehen. Alle Theile derselben sind gleich essbar und von gleich angenehmen Geschmack. Doch enthalten sie im rohem Zustande auch noch einen widerlichen Stoff, der von dem Wasser in welchem man sie ein erstes Mal abkocht, aufgenommen und mit demselben abgegossen wird. Ich bemerkte bei der folgenden Reise, dass meine Begleiter stets diese Vorsicht gebrauchten, wenn sie an den Wachtfeuern die getrockneten Lilienknollen, die wir mitgenommen hatten, kochten. (Erman 1848: III: 245-246.) 
One of the simplest and fastest ways to prepare sarana was to cook the dried bulbs into a thick porridge. Sarana on Kamchatka - in this case a fritillary - was according to von Ditmar cooked into a thick soup and consumed daily instead of bread, together with abundant fish or bird meat (Ditmar 1890: I: 767). Still, there were many other ways to prepare sarana bulbs. Johan Peter Falck informs that "all Siberian peoples eat the sarana bulbs together with meat or cook them separately in milk or water" (Svanberg 1987: 79; 1998: 108). Sarana bulbs were as we have seen (chapter 4) sometimes cooked with milk or used as an addition to milk products.

Sarana bulbs could also be steamed and served with berries. According to Krasheninnikov this was the best and foremost dish in Kamchatka. In his view, it was "both sweet and sour at the same time" and it filled the stomach well. "It can be consumed every day, which makes one almost forget the lack of bread", says Krasheninnikov (1819: II: 314). But, he comments, "even if the dish is filling the preparation of it is horrifying". He observed a woman who "had not washed her hands in a century" put the sarana bulbs in a bowl and punch them with her hands up to her elbows. The hands became white as snow being washed in the fruit. In short, concludes Krasheninnikov (1819: II: 75), "those who are more sensitive do not cope with the preparation of this dish without becoming uncomfortable inside".

Sometimes the bulbs were simply cooked and served whole with birds or fish. Adolph Erman tells that the food was so abundant that even the hungriest would not be able to consume it all:

als der Ort [Chartschinsk] gerühmt wurde an welchem die landesübliche Übersättigung der Gäste aufs wunderbarste gelinge [weil die Wasservögel so Fett sind], denn noch nie sei dort selbst der hungrigste Mann im Stande gewesen, die zwei kleinen Krick-Enten (tschirki), die man ihn vorsetzt, mit den zugegebenen Lilienknollen aufzuessen. (Erman 1848: III: 325.)

The sarana bulbs, Erman mentions round or white sarana [fritillary], could also be cooked, wrapped in a dough of fish flour and then fried in fish fat:

Dann folgten aber nacheinander und bis spät am Abend Chaikes oder jetzt ziehende Lachse, frisch gekocht und mit Fruchtsäften zubereitet, in Milch gesottener Jukola, und anderes Gebraten, so wie, als Krone des Mahles, vortrefflige Lilienknollen (Sarana'), theils gekocht und mit einen Teige aus Fischmehl (getrockneten und zerriebenen Roogen oder Porsa) umgeben, theils in Fischfett gebraten. (Erman 1848: III: 245-246.)

The taste of cooked sarana has been compared to sweet or baked chestnut. Adolph Erman found the taste of sarana delicious. He describes sarana bulbs as excellent food (Erman 1848: III: 161). According to Karl von Ditmar, who calls it "pagan food", the taste is similar to potato: 
$\mathrm{Zu}$ dieser heidnischen Speisen gehörten vor Allem Jukola (getr. Lachs), dann Ssarane, gekochte, den Kartoffeln ähnlich schmeckende Knollen der Fritillaria kamtschatica, Kiprei [Epilobium] und ähnliche Sachen. (Ditmar 1890: I: 371.)

Or sweeter than potato, when cooked and fried:

$\mathrm{Zu}$ den gereichten Speisen gehörte auch eine echt kamtschadalische, die ich in der Folgezeit nur zu gut kennen lernte, nämlich die Wurzelknollen der Fritillaria sarane, welche gekocht und gebraten der Kartoffel ähnlich schmecken, nur vielleicht etwas süsslicher. (Ditmar 1890: I: 139.)

There seem to have existed many recipes for preparing sarana, but the travellers and eyewitnesses do not account for details. This can be due to a lack of knowledge, as few of the upper-class men who travelled in Siberia as explorers had probably ever set foot in a kitchen or cooked any food by themselves. It can also be due to the biased attitude towards local food many of the travellers possessed. Few of the travellers estimated the significance of sarana correctly as an essential part of the local diet. Most of the travellers mention sarana purely as a substitution to potatoes or bread, complaining about the lack of the two others. Karl von Ditmar comments during his 1851-1855 journey:

Brod ist in den kamtschadalischen Ortschaften eine sehr seltene Erscheinung, wird auch von den Eingeborenen gar nicht vermisst und in der Regel durch Kartoffeln, besonders aber durch Lilienknollen (Ssarana, Fritillaria kamtschatica) ersetzt. (Ditmar 1890: I: 360.)

Bread did not belong to the traditional diet of northern Eurasia. Ditmar correctly observed that the local people did not even miss bread. Bread was (and still is) in comparison extremely important in the European diets and was only partly replaced by potatoes in the 19th century. The lack of bread, potatoes and other familiar food seems to have bothered many of the travellers in Siberia. They were not capable of enjoying the local diet except for some dishes. The boiled bulbs of sarana and other plants were seen as more or less exotic, "pagan", disgusting, strange or, in rare cases, surprisingly tasty. In general the travellers held a distanced attitude towards local food, which made them unable to correctly estimate the significance of sarana for the Kamchatkan diet. In short, von Ditmar:

Bei der mir vorgesetzten Mahlzeit kamen keinerlei Gartenprodukte vor, nicht einmal Kartoffeln, wogegen zum Bratfisch verschiedene gekochte Knollen aufgetischt wurden. Ausser der mir bekannten Ssarana (Fritillaria Sarana) gab es hier noch die gelb blühende Owssjanna (Lilium martagon), sowie die Wostronoshka und Odnolistka, welche den Aussehen und Geschmack nach der Kemtschiga ähnlich sind, aber lilienartige Gewächse zu 
sein scheinen. (Ditmar 1890: I: 622.)

\subsection{Other uses of sarana}

Apart from staple food, some peoples in the North Pacific area gathered sarana bulbs as an extra supply for famine or meagre years. As we have seen (6.1.), bulbs were gathered not only from the plants during the period of bloom but also regularly from vole nests, which supplied both high quality bulbs and nutritious food during winter or difficult times. According to Gawriil Sarytschew, some Aleut groups, sustaining mostly on sea animals, crustaceans, roots and algae, collected sarana bulbs and stored them for spare food:

Das erste und liebste Essen der Aleuten ist das Fleisch solcher Seethiere; ist das verzehrt so nehmen sie ihre Zuflucht zu Schaalthieren, Wurzeln und Seekohl; einige von ihnen sammlen sich zwar im Sommer etwas trocknen Fisch, Saranenwurzel und Fett ein, allein es geht ihnen gewöhnlich bald aus, denn sie haben dessen immer nur wenig, und sparen sich bis zur grössten Not auf. (Sarytschew 1806: II: 126.)

Some Siberian peoples used sarana bulbs in rituals as food for the spirits. E. A. Kreynovich, quoted by Elena S. Novik, has told about a shamanistic session among the Nivkhi. Starting the ritual, sarana root was given to the shaman's helping spirits to eat, implying that spirits ate similar food as humans. The shaman was bound up, and then offerings were made for the spirits before the shaman could begin. Labrador tea (Ledum palustre) and spruce were placed in a cup and water was poured over them. This was water for the helping spirits of the shaman to drink. Sarana and t'irkh roots were also placed into a cup and it was set on the edge of the hearth for the helping spirits of the shaman to eat (Novik 1989: 34).

There is no reliable information of sarana used in medicine in northern Eurasia, but as with most food products, it can be supposed that sarana bulbs might have had some medicinal use. As mentioned before (chapter 2), lilies have been used in medicine in Europe and Asia for a few millennia.

The significance of sarana for the economy of Eurasian peoples is mostly found in the private sphere. Sarana was an important and above all free food article for the local households. It was also an article that could bring profit. It could be sold in the market or elsewhere if there were extra supplies. After the contacts between local people and the outside world intensified and the economy changed under Russian influence, it seems that the significance of gathering in general, and sarana within this context, diminished until almost non-existent today.

Gathering sarana was free of charge and did not require financial or other resources, only time and some technical skill for digging out the plant roots or finding the vole nests. Women, children and young adults usually did the gath- 
ering. Sarana grew in great abundance and there seems to have been no lack of roots. Krasheninnikov tells in his travel account how no other flowers can be seen from a distance in the middle of July when sarana is in bloom in the fields. "The women of Kamchatka", says Krasheninnikov, "as well as the wives of the Cossacks, dig out the roots of this plant in the autumn. Most of the roots they gather from mice. When they have dried the roots in the sun they use them for porridge, pastries and a dish with berries". Extra bulbs were sold for 4-6 roubles per pud at the beginning of the 19th century ( 1 pud $=16,38 \mathrm{~kg})$ (Krasheninnikov 1819: II: 314).

Finally, sarana has also inspired poets and song-makers, thus entering the cultural sphere. In Kamassian (now extinct language) t'ukul, identified as martagon lily, was mentioned in a riddle (Lotz 1954: 375). Sarana gathering among the Itelmen, says David Koester, is seen as a tradition and also as an enjoyment. Modern revival of old traditions has brought sarana back into the lives of Itelmen and a song has been made recently in the honour of gathering sarana, reviving the memories of freedom, togetherness and happiness in the activity (Koester 2002: 51).

\section{Tracking sarana}

In a majority of cases sarana is identified as a kind of Lilium, although its scientific identity includes several plants not belonging to the lilies. Many of the non-Lilium plants called sarana possess bulbs that are edible and used for food, among them the fritillary. It could therefore be concluded that sarana in general signifies a bulb-possessing ("onion-like") plant, or even the bulb or root itself. This explains, though, only part of the plants. The use of the name sarana for non-bulbous plants can theoretically be attributed to similar colour, structure or use as bulbous sarana. Possible is also a transfer of meaning from one language to another, or, as in the case of eastern Siberia, the use of a foreign name to signify different plants.

According to Max Vasmer (1955: II: 576) the Russian plant name sarana, for which he only gives the significance 'martagon lily', is of Tatar origin. Russians possibly borrowed the word from Tatars they came in contact with in the Volga-Ural region. Vasmer informs that all Russians living in the Volga-Ural area know it. In Siberia sarana is considered a Russian loanword, wherefore we can suppose that it spread eastwards with Russian migration. Several languages of Siberia, among them Itelmen, Koryak, Evenki, Even and Ket, possessed names of their own for different edible roots, lilies and other plants that gather under the general Russian plant name sarana.

Sarana as a plant name was already in use in eastern Siberia when Sven Waxell travelled to Kamchatka in the 1740s. How widespread it was we do not know, but it is often mentioned in travel accounts. One possible explanation for 
the frequent use of the word is of course that the explorers mostly came in contact or travelled with Russians (some of the travellers themselves were Russian). Naturally they would use a Russian word to signify the roots they ate or the flowers they observed. Also local people would call the plants sarana in front of Russian or foreign travellers instead of using words in Itelmen or other languages of the region, even if they knew and used the local word. Where travellers quote local words these seem to be not very correct and so far our attempts to verify them have not been successful.

As we have mentioned, several Turkic languages possess the word sarana, albeit for somewhat different plants. This could indicate that sarana is of Turkic origin. Still, the origin of the word and its historical development remain to be solved. In Vasmer's opinion (1955: II: 576) the suggested derivation of sarana from the Tatar word sary, 'yellow', is doubtful, to which we agree. Although this word has a similar form and a colour-etymology would seem suitable for a flower, there is no reason to call the plants yellow, even if yellow could mean any shade from creamy white to orange or brown. As already mentioned, most of the lilies as well as fritillaries are not yellow in colour, but vary from rarely white or yellow-orange to mostly red, bronze or violet. Also the roots are not yellow. Among the other plants called sarana yellow is not predominant, even though variations exist, which is recorded in some of the languages. In Nivkh (Gilyak) there are two words corresponding to the Russian word sarana, kark meaning 'blue sarana', and nork meaning 'orange sarana' (Savel'yeva \& Taksami 1965: 379; 1970: 141, 212).

The yellow colour must, of course, be considered within the context of identifying the different sarana botanically, but linguistically it is unlikely that the etymology of sarana lies in Turkic sary. A detailed analysis is beyond the scope of this article, wherefore we will limit ourselves to some reflections.

One possible explanation for the origin of sarana can be found in a Turkic verb root, used in among others Tatar, Ottoman, Turkish, Azeri and Chagatai: sar-, sari- 'to wind, to wrap' (see Budagov 1869: I: 685). The verb root sarexists also in Crimean Tatar, Kazakh, Khakass, Chuvash and Kipchak in slightly different forms or derivations, but with similar significance (see Räsänen 1969: 402). The bulbs of sarana are usually described as wrapped in layers or fleshy leaves. This is specific for most of the "onion-like" plants found under the denotation sarana. The "wrapped" root is a visible characteristic that differentiates the plants called sarana from other plants. In several Turkic languages garlic is sarmïsak, sarmusak, in Mongolian sarimsag (capuмcaz). Sarmug in Mongolian and Buryat means 'turnip' (Lessing 1960: 676). As mentioned, sarana in some cases signifies the bulb itself, which gives the name to the plant.

It would have been convenient for the users of sarana to name the plants according to the roots, since mainly the bulbs were used from the plants. It is 
possible that from the original meaning of 'wrap' the plant name sarana, during its historical development, has come to signify also other plants with bulbs and further, plants that possess similar aspect or structure, and even further, plants that in some way, directly or indirectly, remind of some or one of the plants called sarana. In Russian sarana has acquired a wide range of meanings, which has led to a need to distinguish between the different plants through additional characteristics such as colour or place of growth (see chapter 3). Through Russian the word sarana has spread in Siberia and also in northern America.

Many questions remain open about sarana, but we will at least try to answer one of them. At the beginning of this article we quoted Sven Waxell. During his journey to Kamchatka he observed and tasted the bulbs of a yellow lily called sarana. The second quote was by von Kittlitz who saw a dark purple flower. We can identify the second sarana as Fritillaria camschatcensis, but what flower did Waxell see?

There is always a chance that Waxell observed one plant or maybe only quoted hearsay, and tasted the bulbs of another plant, and that both were called sarana. This Russian loanword carries many meanings in Kamchatka. He could have observed a yellow sarana lily and eaten the root of the purple sarana, Fritillaria camschatcensis, or he could have misunderstood the connection between the flower and the root. In this context it can be mentioned that in Waxell's account also another lily figures. He calls it cheremcha, and says that the local people on Kamchatka collected it for food. This plant, с̌еremša (черемша) in Russian, is no lily but belongs to the Allium species (Allium victoralis). Other travellers to Kamchatka mention it as well (Erman 1848: III: 326; Margaritov 1899: 80; Hultén 1927: 240).

Analysing the possibilities we can suppose that Waxell observed the wheel lily, Lilium medeoloides, which also has been called sarana or sarana-ovsjanka in Russian. Its flowers are yellow or orange and it resembles Lilium martagon. It grows in large areas on southern Kamchatka and is characteristic of the meadows and birch forests of the lowland. The bulbs were collected for food (Hultén 1927: 243). It is therefore very probable that Waxell tasted this lily and that the sarana ovsjanka or ovsjanka should be identified as Lilium medeoloides.

\section{References}

Anikin = Аникин, А. Е. 2000: Этимологический словарь русских диалектов Сибири. Новосибирск.

Bawden, Charles 1997: Mongolian-English dictionary. London.

Birket-Smith, Kaj 1953: The Chugach Eskimo. Copenhagen.

Budagov = Будагов, Лазар 1869: Сравнительный словарь туреико-татарских наречий. Санкт-Петербург.

Byhan, Arthur 1909: Die Polarvölker. Leipzig. 
Castrén, M. A. 1855: Wörterverzeichnis aus den samojedischen Sprachen. Edited by Anton Schiefner. St. Peterburg.

Cheremisov \& Rumyantsev = Черемисов, К. М. \& Румянцев, Г. Н. 1937: Монгольско-русский словарь. Ленинград.

Clark, Lewis J. 1976: Wild flowers of the Pacific Northwest, from Alaska to Northern California. Sidney, British Columbia.

Coffey, Timothy 1993: The history and folklore of North American wildflowers. New York.

Dal' = Даль, Владимир И. 1955: Толковый словарь живого великорусского языка. Москва.

Dimitriyev = Димитриев, В. Д. 1948: Тюркские елементи в русском языке. Москва.

Ditmar, Karl von 1890: Reisen in Kamtschatka in den Jahren 1851-1855. St. Petersburg.

Donner, Kai 1915: Bland samojeder $i$ Sibirien. Helsingfors.

Eidlitz, Kerstin 1969: Food and emergency food in the circumpolar area. Uppsala.

Erman, Adolph 1848: Reise um die Erde durch Nord-Asien und die beiden Oceane in den Jahren 1828-1830. Berlin.

Fedotov = Федотов, М. Р. 1996: Этимологический словар чувашского языка. Чебоксары.

Fremstad, Eli \& Paal, Jaanus 1993: Ethnobotany in Kamchatka and in Norway. - Blyttia 51: 29-38.

Gmelin, Johann Georg 1747: Flora Sibirica. Petropoli.

Gunda, Béla 1949: Plant gathering in Eurasia. - Southwestern Journal of Anthropology 5: 369-378.

Gunda, Béla 1981: On the origins and spread of agriculture. - Current Anthropology 22: 81-82.

Hauenschield, Ingeborg 1989: Türksprachige Volksnamen für Kräuter und Stauden. Wiesbaden.

Heller, Christine A. 1953: Edible and poisonous plants of Alaska. Anchorage.

Hedrik, U. P. 1919: Sturtevant's Notes on Edible Plants. Report of the New York Agricultural Experiment Station 1919: 2. New York.

Hrdlicka, Ales 1945: The Aleutian and Commander Islands and their inhabitants. Philadelphia.

Hudgins, Sharon 2003: Raw liver, singed sheep's head, and boiled stomach pudding: encounters with traditional Buriat cuisine. - Sibirica. Journal of Siberian Studies 3: $131-152$.

Hultén, Eric 1927: Flora of Kamtchatka and the adjacent islands. Kungl. Svenska Vetenskapsakademiens Handlingar 3 Ser. 5:1. Stockholm.

Jochelson, Waldemar 1908: The Koryak. The Jesup North Pacific Expedition 6. New York.

Jochelson, Waldemar 1910: The Yukaghir and the yukaghirized Tungus. New York.

Joki, Aulis J. 1944: Kai Donners Kamassisches Wörterbuch nebst Sprachproben und Hauptzüge der Grammatik. Lexica Societatis Fenno-Ugricae VIII. Helsinki.

Katanov = Катанов, Н. Ф. 1891: Поездка къ Карагасамъ въ 1890 году. С. Петербург. 
Kittlitz, Friedrich Heinrich von 1858: Denkwürdigkeiten einer Reise nach den russischen Amerika. Gotha.

Koester, David 2002: When the Fat Raven sings: Mimesis and environmental alterity in Kamchatka's environmentalist age. - E. Kasten (ed.), People and land. Pathways to reform in post-Soviet Siberia. Berlin. 45-62.

Krasheninnikov = Крашенинников, Степан 1819: Описание земли Камчатки. Санкт-Петербург.

Le Strange, Richard 1977: A history of herbal plants. London.

Lessing, Ferdinand D. (ed.) 1960: Mongolian-English dictionary. Berkeley.

Lotz, John 1954: Kamassian verse. - Journal of American Folklore 67: 369-377.

Lundquist, Kjell 2005: Lilium martagon L. Krolliljans introduktion och tidiga historia $i$ Sverige intill år 1795 i en europeisk liljekontext. Alnarp.

Manninen, Ilmari 1931: Überreste der Sammlerstufe und Notnahrung aus dem Pflanzenreich bei den nordeurasischen, vorzugsweise den finnischen Völkern. - Eurasia Septentrionalia Antiqua 6: 30-48.

Margaritov = Маргаритов, В. 1899: Камчатка и ее обитатели. Санкт-Петербург.

Moerman, Daniel E. 1998: Native American ethnobotany. Oregon.

Novik, Elena S. 1989: The archaic epic and its relationship to ritual. - Soviet Anthropology and Archaeology 28: 2: 20-100.

Pallas, Peter Simon 1776: Reise durch verschiedene Provinzen des Russischen Reichs. S:t Petersburg.

Potapov = Потапов, Л. П. 1953: Пища алтайцев. - Сборник Музея антропологии и этнографии Ак. наук СССР 14.

Radloff, Wilhelm 1884: Aus Sibirien. Leipzig.

Radloff, Wilhelm 1911: Versuch eines Wörterbuches der Türk-Dialecte. St. Peterburg.

Räsänen, Matti 1923: Die tatarischen Lehnwörter im Tscheremissischen. Mémoirs de la Société Finno-Ougrienne L. Helsinki.

Räsänen, Matti 1969: Versuch eines etymologischen Wörterbuchs der Türksprachen. Lexica Societatis Fenno-Ugricae XVII. Helsinki.

Sarytschew, Gawriil 1806: Gavrila Sarytschew's achtjährige Reise im nordöstlichen Sibirien, auf dem Eismeere und dem nordöstlichen Ozean. Leipzig.

Savel'yeva \& Taksami = Савельева, В. Н. \& Таксами, Ч. М. 1965: Русско-нивхский словарь. Москва.

Savel'yeva \& Taksami = Савельева, В. Н. \& Таксами, Ч. М. 1970: Нивхско-русский словарь. Москва.

Schelechof, Grigori 1793: Erste und zweyte Reise von Ochotsk in Sibirien durch den ostlichen Ocean nach den Küsten von Amerika 1783-1789. St. Petersburg.

Shipova = Шипова, Е. Н. 1976: Словарь тюркизмов в русском языке. Алма-Ата.

Steller, Georg Wilhelm 1774: Beschreibung von dem Lande Kamtschatka. Frankfurt Leipzig.

Suzue, Mantarô \& Shimonaga, Kenji 1933: Môko daijiten. Tôkyô.

Svanberg, Ingvar 1987: Turkic ethnobotany and ethnozoology as recorded by Johan Peter Falck. - Svenska Linnésällskapets Årsskrift 1986-1987: 53-118.

Svanberg, Ingvar 1998: Johan Peter Falck som svensk etnobiolog i rysk tjänst. - Roger Gyllin, Ingvar Svanberg \& Ingmar Söhrman (eds.), Bröd och salt: svenska kulturkontakter med öst. En vänbok till Sven Gustavsson. Uppsala. 89-126. 
Svanberg, Ingvar 2004a: Brandgul lilja (Lilium bulbiferum) i allmogens trädgårdar. Uppland 2004: 99-116.

Svanberg, Ingvar 2004b: Tjuktjernas användning av vilda växter: $F$. R. Kjellmans etnobotaniska fältstudier 1878-79. Europeiska studier i etnobiologi 2. Uppsala.

Svanberg, Ingvar \& Lindin, Leif 1986: Traditional reindeer husbandry among the Evens of Kamchatka in the beginning of the 1920's. - Hugh Beach (ed.), Contributions to circumpolar studies. Uppsala Research Reports in Cultural Anthropology 7. Uppsala. $151-179$.

Tanaka, Tyôzaburô 1976: Tanaka's cyclopedia of edible plants of the world. Tokyo.

Togan, Zeki Velidî 1969: Hâtıralar. İstanbul.

Tret'yakov" = Третьяковъ, П. И. 1871: Туруханскій край, его природа и жители. С. Петербургъ.

Tugutov = Тугутов, И. Е. 1958: Материальная культура бурят: этнографическое исследование. Улан-Удэ.

Turner, Nancy Chapman \& Bell, Marcus A. M. 1973: The ethnobotany of the Southern Kwakiutl Indians of British Columbia. - Economic Botany 27: 257-310.

Turner, Nancy J. 1973: The ethnobotany of the Bella Coola Indians of British Columbia. - Syesis 6: 193-220.

Turner, Nancy J. \& Efrat, Barbara S. 1982: Ethnobotany of the Hesquiat Indians of Vancouver Island. Victoria.

Turner, Nancy J. \& Thomas, John \& Carlson, Barry F. \& Ogilvie, Robert T. 1983: Ethnobotany of the Nitinaht Indians of Vancouver Island. Victoria.

Turner, Nancy J. \& Thompson, Laurence C. \& Thompson, M. Terry \& York, Annie Z. 1990: Thompson ethnobotany: Knowledge and usage of plants by the Thompson Indians of British Columbia. Victoria.

Vasmer, Max 1955: Russisches etymologisches Wörterbuch. Heidelberg.

Waxell, Sven 1953: Den stora expeditionen. Utgiven och med kommentar försedd av Juri Semjonow. Stockholm.

Sabira Ståhlberg <sabiras@luukku.com>

Ingvar Svanberg <ingvar.svanberg@eurasia.uu.se>

Department of Eurasian Studies

Uppsala university

P.O. Box 514

SE-751 20 Uppsala 